\title{
Netrin Receptor DCC
}

National Cancer Institute

\section{Source}

National Cancer Institute. Netrin Receptor DCC. NCI Thesaurus. Code C17908.

Netrin receptor DCC (1447 aa, $158 \mathrm{kDa}$ ) is encoded by the human DCC gene. This protein is involved in both axonal guidance and the regulation of apoptosis. 